\title{
GRAZING EFFECTS OF THE INVASIVE MUDSNAIL, Potamopyrgus antipodarum AND TWO NATIVE INVERTEBRATES
}

\author{
AMY C. KRIST ZOOLOGY AND PHYSIOLOGY DEPARTMENT \\ UNIVERSITY OF WYOMING — LARAMIE
}

\section{$\downarrow \quad$ INTRODUCTION}

Although many efforts are being made to address ecological impacts of invasive species, very little effort has been made to address the evolutionary impacts of biological invasions (Sakai et al. 2001, Cox 2004). Yet these impacts are likely to be widespread; invasive species have been shown to alter patterns of natural selection or gene flow (Parker et al. 1999), and many of the best examples of rapid evolution involve invasive species interacting with native species (Reznick and Ghalambor 2001, Strauss et al. 2006). Hence, I am addressing both the ecological and the potential evolutionary consequences of the invasive New Zealand mud snail, Potamopyrgus antipodarum on native benthic macroinvertebrates in the Greater Yellowstone Area (GYA).

Several characteristics of Potamopyrgus antipodarum make it a likely selective agent on native invertebrates. First, it has achieved very high densities in the invasive range $\left(500,000 / \mathrm{m}^{2}\right.$ in some areas of the Greater Yellowstone Ecosystem; Hall et al. 2003) and dominates these communities (Kerans et al. 2005, Hall et al. 2006), suggesting $P$. antipodarum have a strong impact on the biotic and abiotic environment. In fact, Hall and colleagues (2003) showed that $P$. antipodarum consumed $75 \%$ of gross primary productivity, and Riley et al (in review) showed that they reduce periphyton biomass (the microscopic algae, fungi, and bacteria on substrata). Because the growth of individuals and populations of algivores can be limited by the abundance of algae (reviewed in Lamberti 1996), this consumption of the majority of resources by $P$. antipodarum is likely to have a negative effect on other benthic herbivores. Second, studies have shown either direct (Riley et al. in review, Krist and Dybdahl in prep.) or indirect (Kerans et al. 2005) evidence that $P$. antipodarum is competing with native invertebrates. These detrimental consequences to the fitness of native invertebrates may either reduce their population sizes or, with sufficient time and genetic variation, lead to evolutionary change in populations of natives.

In July 2006, I conducted a grazing experiment to determine which native species are most likely affected by $P$. antipodarum. I chose the native species based on availability and on recent studies that indicate at least five groups of native macroinvertebrates are affected by $P$. antipodarum. In experimental conditions, two species of native snails, Pyrgulopsis robusta (like $P$. antipodarum, a member of the Hydrobiidae), and Fossaria sp. (Lymnaeidae) exhibit reduced growth in the presence of $P$. antipodarum (Riley et al in review, Krist and Dybdahl, in prep.). Inter-specific competition is also suggested by negative associations between the density of $P$. antipodarum and several families of insects in a river basin of the Greater Yellowstone Ecosystem (Kerans et al. 2005).

In the experiment, I allowed grazers to consume periphyton on tiles that had been 
colonized in the stream. By examining the periphyton remaining on the tiles after grazing and comparing it to the ungrazed control tiles, I could determine the extent of overlap in diet between $P$. antipodarum and the native species. Species with the greatest overlap in diet with $P$. antipodarum are the most likely to be affected by the invasion.

\section{$\downarrow \quad$ METHODS}

To obtain periphyton for our experiment, I placed unglazed tiles $\left(23.5 \mathrm{~cm}^{2}\right.$ area) in Polecat Creek in early July 2006. Periphyton is a layer of algae, bacteria, and fungus in a non-living matrix that covers rocks and plants in freshwater. The tiles were attached to platforms that excluded benthic grazers (Lamberti and Feminella 1996). All platforms were placed in unshaded areas with similar flow regimes. The tiles were colonized with periphyton for 18 days.

In late July 2006, I collected $P$. antipodarum, a native snail Fossaria sp., and the caddisfly Brachycentrus sp.. In each experimental unit, I placed a single tile with individuals of one of the species of grazers. The number of animals differed by species because I placed an equivalent amount of ash free dry mass in each chamber. I used length-mass regressions (Hall et al. 2006, Riley unpublished, Benke et al. 1999) to convert body length to ash free dry mass. I measured random samples of 20-30 individuals of each species to obtain a mean length for these regressions. I used the same biomass of $P$. antipodarum that had been shown to significantly depress biomass and chlorophyll $a$ in a similar study (Winterbourn and Fegley 1989), but adjusted for the tile size and duration of the current experiment.

In addition to the three species, I included ungrazed controls containing a single tile and no animals. There were eight replicates for each treatment. I placed the experimental chambers in the stream and allowed the animals to graze for 48 hours. The chambers were placed at a depth that covered the animals and the tile but allowed some air at the top of the cage. The air pocket is required for the air-breathing snail Fossaria sp.

\footnotetext{
Experimental chambers were constructed from 156. $25 \mathrm{~cm}^{2}$ square plastic
}

storage containers. The plastic was removed from each side and top and replaced with nylon window screening (1.2 $\mathrm{mm}$ size pores). The screen allowed fresh water to flow through the chambers. I attached the chambers to a single brick by threading a $14 \mathrm{~cm}$ long bolt through a hole in the bottom of the chamber and attaching nuts and washers to the bottom of the brick to secure the two together.

At the end of the experiment, my field assistants and I removed all of the animals from each cage and scrubbed the remaining periphyton off of the tiles with brushes. I used the slurry to measure algal assemblage, chlorophyll $a$, and ash free dry mass (AFDM). We preserved $1 \mathrm{ml}$ of the slurry in glutareldehyde to determine algal assemblage. I used vacuum filtration to concentrate $5 \mathrm{ml}$ of the slurry onto a glass fiber filter (Pall A/E, $25 \mathrm{~mm}$ ) to measure chlorophyll $a$ and the remaining slurry onto a glass filter to measure AFDM.

I obtained pheophyton-corrected measures of chlorophyll $a$ by extracting the chlorophyll $a$ from the filters using buffered ethanol. Then, I measured absorbance with a flourometer before and after the addition of $\mathrm{HCl}$. I measured AFDM of each sample as the difference between the dry mass ( 24 hours at $60^{\circ}$ C) and the mass after ashing ( 1 hour at $500^{\circ} \mathrm{C}$ ).

To determine algal assemblage, I made two kinds of slides. One type was used to identify non-diatom algae and the second type was used to identify diatoms. I diluted the solution to $4 \mathrm{ml}$ with distilled water. To make the first type of slide, I used vacuum filtration to place a $3 \mathrm{ml}$ sample onto a metrical membrane filter (Pall GN-6 grid, $25 \mathrm{~mm}$ ) and mounted the filters on glass microscope slides using 2hydroxypropyl methacrylate (HPMA) resin. Permanent mounts were made by drying the resin $\left(24 \mathrm{hr}\right.$ at $\left.60^{\circ} \mathrm{C}\right)$, mounting cover slips with additional resin and drying again ( $48 \mathrm{hrs}$ at $60^{\circ}$ C). To make the slides for identifying diatoms, I "cleaned" a subsample of the algal assemblage with bleach to remove all organic matter. This process empties the diatom exoskeleton (frustule) of organic matter, leaving the structure easier to observe. To identify the diatoms to genus, I made a few permanent slides of samples from each treatment. I added naphrax to a drop of the cleaned diatom sample, placed a coverslip over the solution and heated until bubbly. Diatom counts of the cleaned samples were made 
in a Palmer Maloney cell. Diatoms were identified using several keys and references (Patrick and Reimer 1966; Prescott 1978; Lowe and Laliberti 1996).

To determine whether each species significantly reduced the concentration of chlorophyll $a$ or biomass (AFDM), I used Welch's two sample t-tests to compare values for each species (treatment) to the controls. I used a Bonferroni correction for the $p$ value because of multiple tests $(p=0.017)$.

\section{$\uparrow \quad$ RESULTS}

I found that all three species significantly reduced the amount of chlorophyll $a$ (Figure 1). However, only the caddisfly Brachycentrus sp. marginally reduced the biomass of periphyton (Figure 2). Comparisons were made against the controls for each species with a Welch's two sample t-test.

After learning to identify and differentiate diatom genera, my student Caroline Charles counted two of the eight replicates per treatment. Preliminary analysis of these diatom assemblages revealed that the variance among samples was extremely high (e.g., Figure 3). Based on this initial analysis, I decided not to count the remaining six replicates per treatment (total 24 samples), and to repeat this study in the summer of 2007 with increased replication.

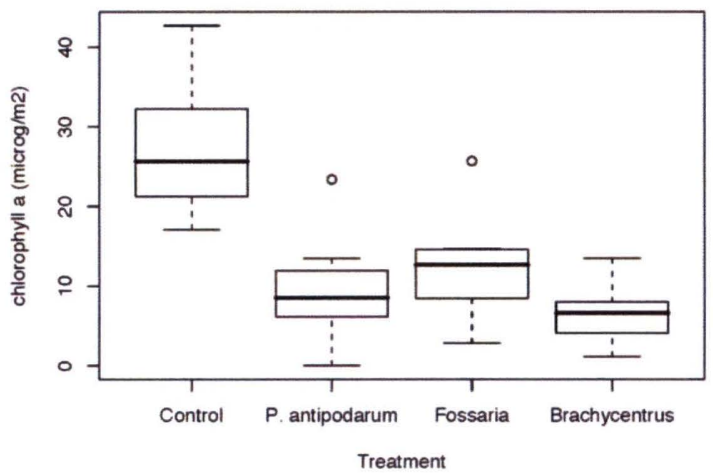

Figure 1. Concentration of chlorophyll a $(\mu \mathrm{g} / \mathrm{m} 2)$ on tiles measured among treatments of the experiment. Grazers were absent in the controls. Concentration of chlorophyll a was significantly lower than controls on tiles grazed by the invasive snail $P$. antipodarum $(\mathrm{t}=$ $4.00, \mathrm{df}=11.9, \mathrm{p}=0.002$ ) the native snail Fossaria sp. $(\mathrm{t}=3.90, \mathrm{df}=13.4, \mathrm{p}=0.002)$, and the caddisfly Brachycentrus sp. $(\mathrm{t}=6.43, \mathrm{df}=9.7, \mathrm{p}<0.001)$.

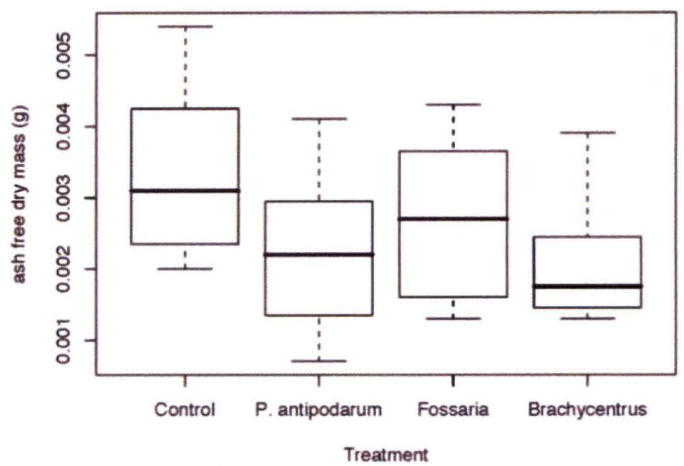

Figure 2. Ash free dry mass (g) on tiles measured among treatments of the experiment. Grazers were absent in the controls. Biomass was not significantly lower than controls for the invasive snail $P$. antipodarum $(\mathrm{t}=1.80, \mathrm{df}=12.69, \mathrm{p}=0.096)$, and the native snail Fossaria sp. $(\mathrm{t}=1.11$, df $=14.0, \mathrm{p}=$ 0.285 ), but was marginally decreased by the caddisfly Brachycentrus sp. $(\mathrm{t}=2.46, \mathrm{df}=12.8, \mathrm{p}=0.029)$. I used a Bonferroni correction for the $\mathrm{p}$ value because of multiple tests $(\mathrm{p}=0.017)$.

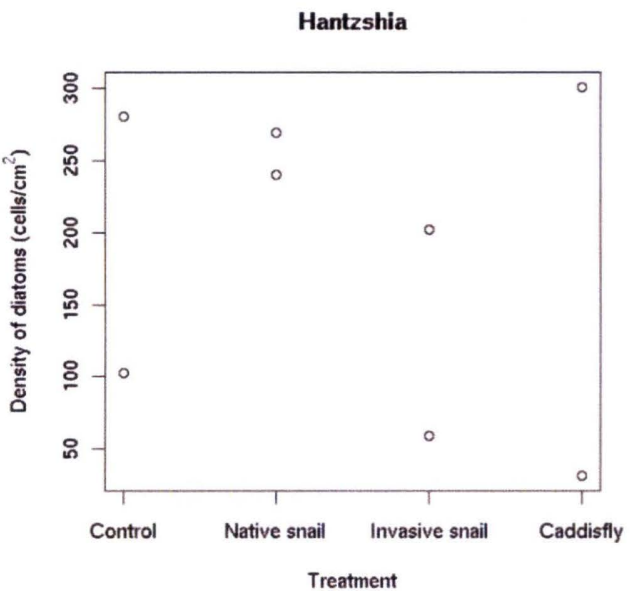

Figure 3. Density (cells $/ \mathrm{cm}^{2}$ ) of the diatom Hantzshia among treatments of the experiment. Grazers were absent in the controls. Each dot represents the density of one sample; only two samples are shown for each treatment. The native snail is Fossaria sp. and the exotic snail is the New Zealand mudsnail $P$. antipodarum.

\section{$\downarrow \quad$ DISCUSSION}

I estimated benthic algal biomass by measuring chlorophyll $a$ and ash free dry mass (AFDM). Interestingly, chlorophyll $a$ was reduced by each of the grazing species but biomass (AFDM) was not significantly decreased by either snail species and was only 
marginally decreased by the caddisflies. This incongruence in the results may reflect what chlorophyll $a$ and AFDM measure. Chlorophyll $a$ only measures the algal portion of periphyton because this pigment is specific to algae. Additionally, our measure of chlorophyll $a$ only includes living cells (concentration of chlorophyll $a$ is pheophyton-corrected). In contrast, AFDM includes inorganic matter and living and non-living non-algal organic matter such as fungi, bacteria, and detritus (Stevenson 1996). Hence, a significant reduction of chlorophyll $a$ and not AFDM suggests that the grazers may be preferentially feeding on the living algal cells and leaving behind the dead and non-algal matter. Also, algal biomass may not be reduced if large, slow growing diatoms are grazed and replaced by small, fast growing diatoms species (Steinman 1996). However, this explanation is unlikely because it would not lead to the reductions in chlorophyll $a$ in the grazed tiles that I observed.

The algal assemblage on the tiles grazed by each species should reveal the types of algae eaten and the relative amounts of each species compared to the controls. Comparisons of algal assemblage between the invasive mudsnail and the native species should reveal the extent of dietary overlap. Native invertebrates with the greatest overlap in diet are the most likely to be negatively affected by the invasive $P$. antipodarum. However, we did not collect all of the data on algal assemblage, so conclusions about algal assemblage are pending analysis of the data from the 2007 grazing experiment.

In the few samples that my student Caroline Charles counted, certain species of diatoms had higher frequencies in the grazed tiles than in the controls. This unexpected result may be caused by increased replication rates when competitors were eliminated by grazing. This result may also be caused by increased light or other nutrients for understory diatoms as overstory diatoms were removed by grazing (Steinman 1996).

From these preliminary and incomplete results, we can conclude that the invasive $P$. antipodarum and the two native species are all consuming periphyton. Hence, the two native species are likely to be affected by the invasive snail. Ongoing analysis of algal assemblage from the more recent experiment will reveal the extent of dietary overlap and hence the species which are most likely to be affected by the invasive mudsnail, P.antipodarum.

Possible affects of the mudsnail on natives include reduced population sizes and possibly extirpation caused by reduced fitness of natives. Additionally, native species may grow more slowly under depleted resources, resulting in plastic changes in body size and life histories. Plastic responses might include smaller size at metamorphosis and, since adult insects do not grow, smaller adult sizes. Size is positively correlated to fecundity in most invertebrates, so smaller adult sizes should further decrease fitness. Finally, with sufficient time and genetic variation, decreased fitness from reduced resources may lead to significant evolutionary change in populations of native competitors.

\section{$\downarrow \quad$ Literature Cited}

Benke, A.C. , A.D. Huryn, L.A. Smock, and J.B. Wallace. $1999 . \quad$ Length-mass relationships for freshwater invertebrates in North America with particular reference to the southeastern United Sates. Journal North American Benthological Society. 18: 308-343.

Cox, G.W. 2004. Alien Species and Evolution: The evolutionary ecology of exotic plants, animals, microbes, and interacting native species. Island Press, Washington, D.C., USA.

Hall, R.O. Jr., J.L. Tank, M.F. Dybdahl. 2003. Exotic snails dominate nitrogen and carbon cycling in a highly productive stream. Frontiers in Ecology and the Environment. 1:407-411.

Hall, R.O., M.F. Dybdahl, and M.C. VanderLoop. 2006. Invasive species and energy flow: Extremely high secondary production of introduced snails in rivers. Ecological Applications. In Press

Kerans, B.L., M.F. Dybdahl, M.M. Gangloff, and J.E. Jannot. 2005. Potamopyrgus antipodarum: distribution, density, and effects on native macroinvertebrate assemblages in the Greater Yellowstone Ecosystem. Journal North American Benthological Society. 24:123-138. 
Krist, A.C. and M.F. Dybdhal. in prep. The invasive New Zealand mud snail, Potamopyrgus antipodarum, reduces growth of the native snail, Fossaria sp.

Lamberti , G.A. 1996. The role of periphyton in benthic food webs. In Algal Ecology: Freshwater Benthic Ecosystems (Stevenson, R.J., Bothwell, M.L. and Lowe, R.L. eds). Academic Press, San Diego, USA.

Lamberti, G.A. and J.W. Feminella. 1996. PlantHerbivore Interactions. In Methods in Stream Ecology (F.R. Hauer and G.A. Lamberti eds). Academic Press, San Diego, USA.

Lowe, R. L., and Laliberte, G. D. 1996. Benthic Stream Algae: Distribution and Structure. In: Methods in Stream Ecology (Hauer, F.R. and Lamberti, G.A., eds.). Academic Press Inc. pp. 269-293.

Parker, I.M., D. Simberloff, W.M. Lonsdale, K. Goodell, M. Wonham, P.M. Kareiva, M.H. Williamson, B. Von Holle, P.B. Moye, J.E. Byers, and L. Goldwasser. 1999. Impact: toward a framework for understanding the ecological effects of invaders. Biological Invasions 1:3-19.

Patrick, R. and Reimer, C. W. 1966. The Diatoms of the United States. The Academy of Natural Sciences of Philadelphia, PA.

Prescott, G.W. 1978. How to Know the Freshwater Algae. Wm. C. Brown Company Publishers, IA.

Reznick, D.N. and C.K. Ghalambor. 2001. The population ecology of contemporary adaptations: what empirical studies reveal about the conditions that promote adaptive evolution. Genetica 112113:183-198.
Riley, L.A., M.F. Dybdahl, R.O Hall, Jr. in review. Grazing and competition interaction strengths match patterns of introduced species dominance. Biological Invasions.

Sakai, A.K., F.W. Allendorf, J.S. Holt, D.M. Lodge, J. Molofsky, K.A. With, S. Baughman, R.J. Cabin, J.E. Cohen, N.C. Ellstrand, D.E. McCauley, P. O’Neil, I.M. Parker, J.N. Thompson, S.G. Weller. 2001. The Population Biology of Invasive Species. Annual Review of Ecology and Systematics. 32:305-32.

Steinman, A. D. 1996. Effects of grazers on freshwater benthic algae. In Algal Ecology: Freshwater Benthic Ecosystems (Stevenson, R.J., Bothwell, M.L. and Lowe, R.L. eds). Academic Press, San Diego, USA.

Stevenson, R.J. 1996. An introduction to algal ecology in freshwater benthic habitats. In Algal Ecology: Freshwater Benthic Ecosystems (Stevenson, R.J., Bothwell, M.L. and Lowe, R.L. eds). Academic Press, San Diego, USA.

Strauss, S.Y., J.A. Lau, and S.P. Carroll. 2006. Evolutionary responses of natives to introduced species: what do introductions tell us about natural communities? Ecology Letters 9:357374.

Winterbourn, M.J. and A. Fegley. 1989. Effects of nutrient enrichment and grazing on periphyton assemblages in some springfed, south island streams. New Zealand Natural Sciences. 16:57-65. 